Papera.] BUTLER ON FINER GRINDING OF PORTLAND CEMENT. 343

\author{
(Paper No. 3050.)
}

\title{
"The Finer Grinding of Portland Cement, and the Comparative Value of the Coarser Particles."
}

By David Butler Butler, Assoc. M. Inst. C.E.

THE experiments described in this Paper were undertaken by the Author to investigate the generally-accepted theory as to the inertness of the coarser particles of Portland cement, the results of which suggested the subsequent series of researches as to the effect of extreme fine grinding. As a preliminary experiment, the coarser particles of cement A, Table I, were separated into three degrees of coarseness, viz., those which would not pass through a sieve having 50 meshes per lineal inch, those which passed a 50-mesh sieve and were retained on a 70-mesh, and those which passed a 70-mesh sieve and were retained on a 120-mesh, and briquettes formed from the grit thus obtained. To ensure that the cohesive strength developed was actually due to the cementitious value of the coarse particles themselves, and not to fine cement dust or flour adhering to them, each lot was thoroughly washed by shaking it briskly with water in a stoppered bottle, decanting the turbid fluid, adding fresh water, and repeating the operation until the water was no longer turbid; about ten changes of water sufficed for this purpose. The washed substance was then immediately filled into an ordinary briquette mould of 1 square inch section, lightly shaken, without ramming, to eliminate any air-bubbles, and placed under water. On examination a day or two afterwards, the mass was found to have hardened considerably, and in a few days, according to the size of the grit, it was sufficiently hard to bear removal from the moulds. The briquettes thus formed were tested for tensile strain at the end of 6 months and 12 months respectively, with the results given in Table I. As the 6 months' test indicated clearly that the coarse particles thus treated had a certain value, a set of experiments was instituted with four other cements, B, C, D and E. The results corroborated those obtained in the first instance, as will be seen on reference to the same Table.

The coarse residue has hitherto been considered inert, and by 
344 BDTLER ON FINER GEINDING OF PORTLAND CEMENT. [Selected

TABLE I.

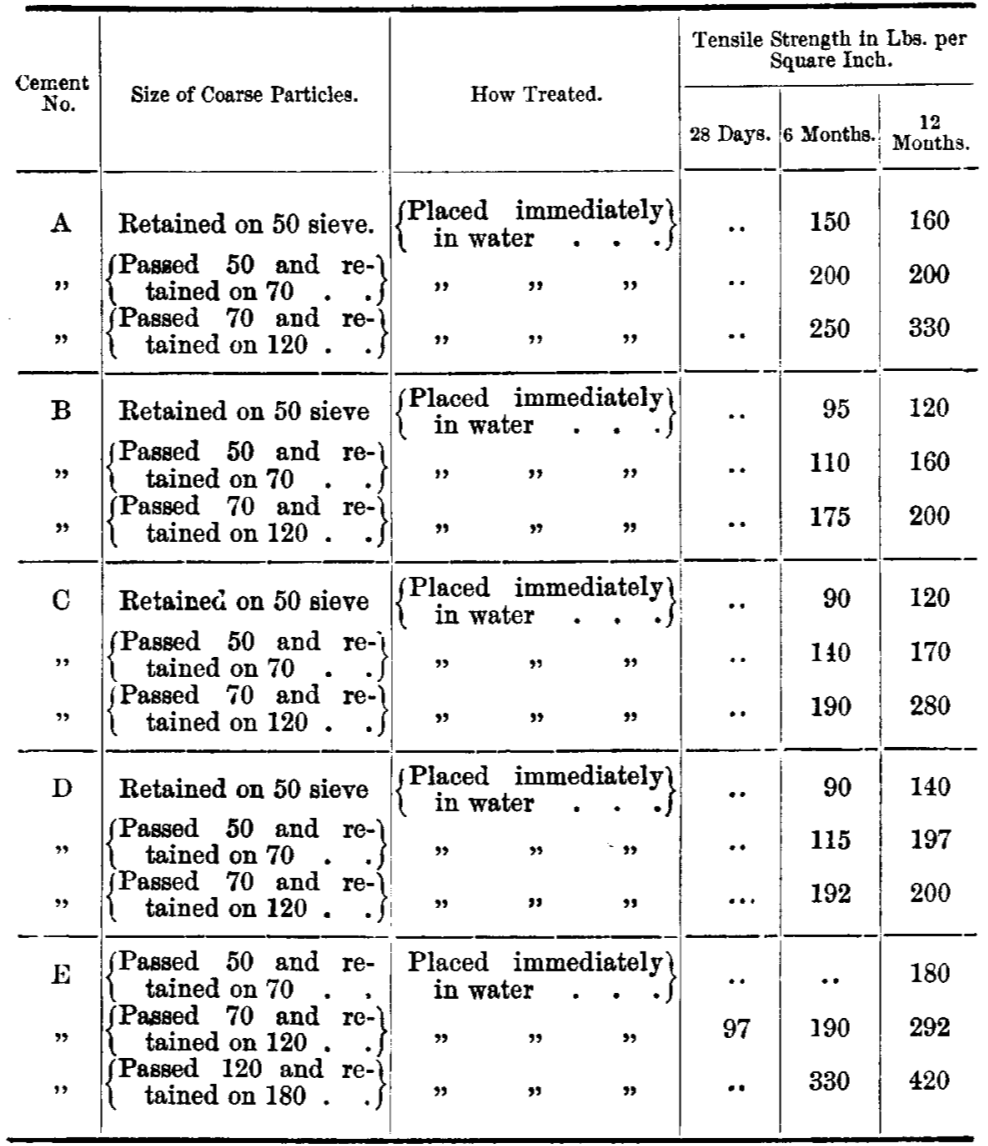

some authorities has been even regarded as an adulterant, but the above results conclusively demonstrate that such is by no means the case. The Author therefore proceeded to ascertain more exactly the relative value of the particles of different sizes, and also whether their total removal from the cement affected the strength of the material. If, after a considerable lapse of time, the coarser particles had a certain value, it seemed possible that the extreme fine grinding of cement might not be such an unmixed advantage as was generally supposed, but that it simply enabled the cement to more quickly attain its greatest strength, by reason of the water being able to more readily combine with 
fine than with the coarse particles. In that case the ordinary 7-day or 28-day tests with very fine cements were more or less delusive, for though a finely-ground cement would show to greater advantage within such limited periods, the coarser cement would ultimately be equally strong; in other words, that the "growing" power of cement, or its property of increasing in strength with age, was largely due to the gradual incorporation of the coarser particles. The following experiments, though supporting this theory to a certain extent, conclusively demonstrate the advantages of finely-ground cement.

In order to procure a fair representation of English cements, samples were obtained from the principal manufacturers in the four chief centres of the industry, viz., cement $F$ from the Lias districts of Warwickshire, cement $G$ from the Northfleet shore of the Thames, cement $\mathrm{H}$ from the Grays shore of the Thames, and cement I from the Medway district. Comparative tests were made of each sample under the following conditions: (1) As received from the manufacturer; (2) reground (in the Author's mill) so as to practically all pass a 180-mesh sieve; (3) all particles removed that would not pass a 180 -mesh sieve, and an equal quantity of grains of sand of exactly the same size substituted. The value of each cement thus treated was ascertained by determining its tensile strength in the ordinary way at 7 days, 28 days, 3 months, 6 months and 12 months, both neat and with 3 parts of standard sand, and the results of this series of tests are given in Table II.

Referring first to cement F, it will be seen that the effect of grinding it extremely fine is that when gauged neat it is slightly stronger than the original cement at 7 days, but shows very little increase at the 28 days, and then gradually falls off, being 22 per cent. weaker at the end of 12 months than the original cement. The 3 to 1 sand briquettes, on the other hand, are 89 per cent. stronger at 7 days than similar briquettes made with the original cement, and continue to increase, till, at the end of 3 months, they are actually stronger than the neat briquettes, while at the end of 12 months they are not only 32 per cent. stronger than the sand briquettes of the original cement, but are within 3 per cent. of the strength of the original cement gauged neat.

The effect of substituting sand for the coarser particles is to weaken both the adhesive and cohesive power of the cement, especially at the earlier dates, although at 12 months the neat briquettes thus prepared appear to have nearly canght up the original cement. The results obtained with cements $\mathrm{G}, \mathrm{H}$ and $\mathrm{I}$, corroborate cement $F$ fairly well, and although in some instances 
346 BUTLER ON FINER GRINDING OF PORTLAND OEMENT. [Selected

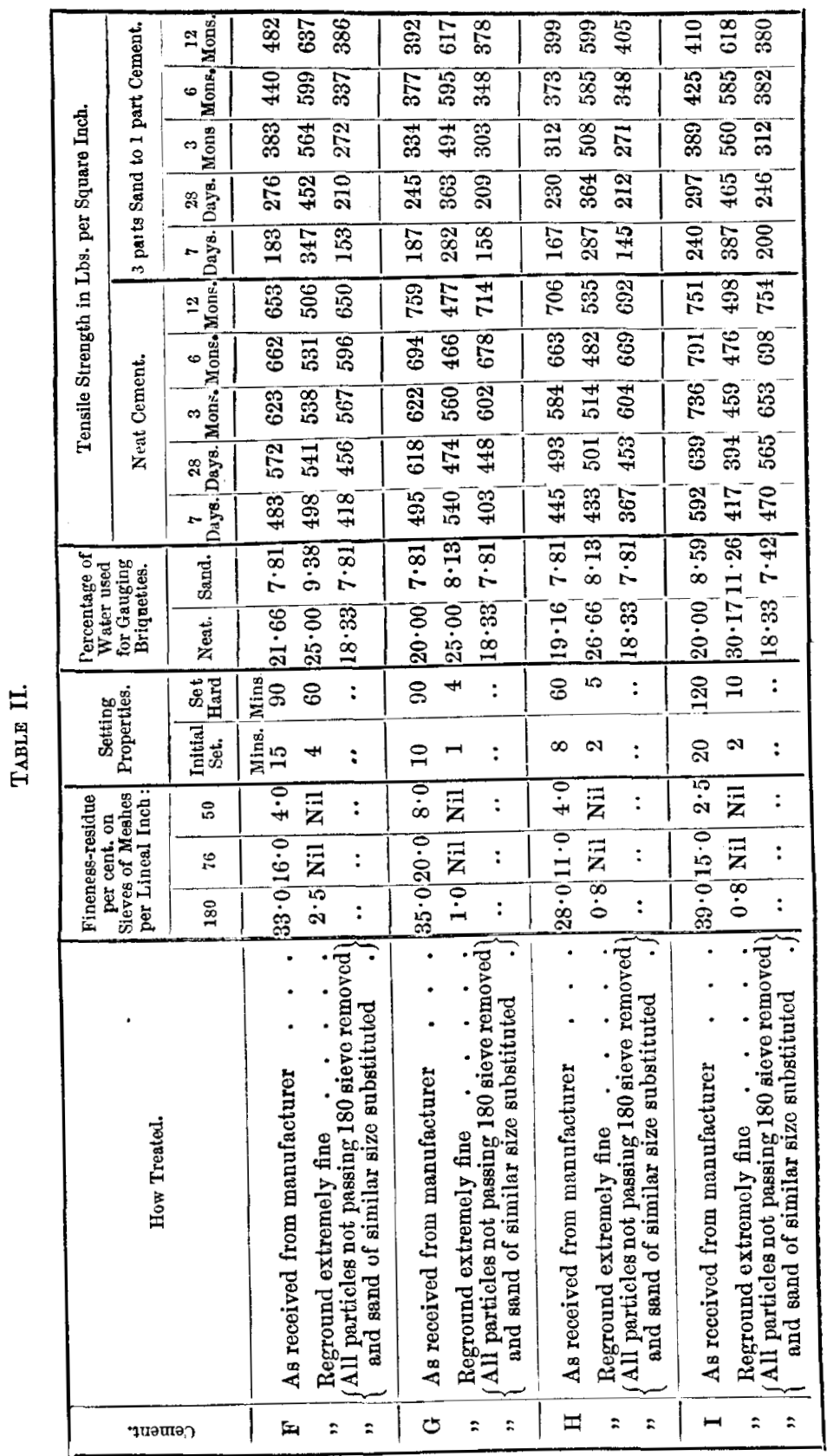




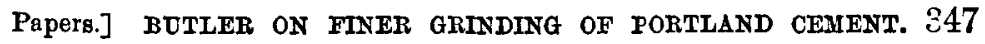

TABLE III.

\begin{tabular}{|c|c|c|c|c|c|c|c|}
\hline \multirow{2}{*}{ Cement. } & \multirow{2}{*}{ Size of Coarse Particles. } & \multirow{2}{*}{\multicolumn{2}{|c|}{ How treated. }} & \multicolumn{4}{|c|}{ Tensile Strength in Lbs, per Square Incb. } \\
\hline & & & & 28 Days. & 3 Months. & 6 Months. & 12 Month8. \\
\hline $\mathbf{F}$ & $\left\{\begin{array}{c}\text { Retained on } 50 \\
\text { sieve }\end{array}\right.$ & $\begin{array}{r}\text { Placed } \\
\text { ately }\end{array}$ & $\left.\begin{array}{c}\text { mmedi- } \\
\text { water }\end{array}\right\}$ & 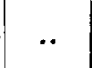 & •. & 95 & 130 \\
\hline$"$ & $\left\{\begin{array}{c}\text { Passed } 50 \text { and re- } \\
\text { tained on } 76\end{array}\right\}$ & $"$ & $"$ & •. & •. & 120 & 170 \\
\hline$"$ & $\left\{\begin{array}{c}\text { Passed } 76 \text { and re- } \\
\text { tained on } 120\end{array}\right\}$ & $"$ & • & • & .. & 245 & 300 \\
\hline$"$ & $\left\{\begin{array}{c}\text { Passed } 120 \text { and } \\
\text { retained on } 180\end{array}\right\}$ & $"$ & $"$ & $\cdots$ & “ & 310 & 360 \\
\hline " & $\left\{\begin{array}{c}\text { Entire residue re- } \\
\text { tained on } 180\end{array}\right\}$ & & & . & 150 & 230 & 290 \\
\hline $\mathbf{G}$ & $\left\{\begin{array}{l}\text { Retained on } 50 \\
\text { sieve }\end{array}\right.$ & $\begin{array}{l}\text { Placed } \\
\text { ately }\end{array}$ & $\left.\begin{array}{c}\text { amedi- } \\
\text { water }\end{array}\right\}$ & ・. & ・. & 47 & 70 \\
\hline$"$ & $\left\{\begin{array}{c}\text { Passed } 50 \text { and } r e- \\
\text { tained on } 76\end{array}\right.$ & $"$ & $"$ & "• & ・• & 105 & 165 \\
\hline$"$ & $\left\{\begin{array}{c}\text { Passed } 76 \text { and re- } \\
\text { tained on } 120\end{array}\right.$ & "' & " & "• & .. & 175 & 300 \\
\hline " & $\left\{\begin{array}{c}\text { Passed } 120 \text { and } \\
\text { retained on } 180\end{array}\right\}$ & $"$ & $"$ & • & * & 185 & 410 \\
\hline$"$ & $\left\{\begin{array}{c}\text { Entire residue re- } \\
\text { tained on } 180\end{array}\right\}$ & $"$ & $"$ & 48 & 133 & 158 & 262 \\
\hline $\mathbf{H}$ & $\left\{\begin{array}{c}\text { Retained on } 50 \\
\text { sieve }\end{array}\right.$ & $\begin{array}{l}\text { Placed } \\
\text { ately }\end{array}$ & $\left.\begin{array}{c}\text { nmedi- } \\
\text { water }\end{array}\right\}$ & ・• & "• & 92 & 145 \\
\hline " & $\left\{\begin{array}{c}\text { Passed } 50 \text { and } \mathrm{re}- \\
\text { tained on } 76 \\
\text { Passed } 76 \text { and re- }\end{array}\right\}$ & $"$ & $"$ & $\cdot \cdot$ & •. & 132 & 235 \\
\hline$"$ & $\left\{\begin{array}{c}\text { tained on } 120 \\
\text { tal }\end{array}\right\}$ & $"$ & $"$ & $\cdots$ & ・. & 200 & 385 \\
\hline$"$ & $\left\{\begin{array}{c}\text { Passed } 120 \text { and } \\
\text { retained on } 180\end{array}\right\}$ & $"$ & " & $\cdots$ & •• & 280 & 360 \\
\hline " & $\left\{\begin{array}{c}\text { Entire residue re- } \\
\text { tained on } 180\end{array}\right\}$ & & $"$ & 72 & 142 & 212 & 272 \\
\hline I & $\left\{\begin{array}{l}\text { Retained on } 50 \\
\text { sieve }\end{array}\right.$ & $\begin{array}{l}\text { Placed } \\
\text { ately }\end{array}$ & $\left.\begin{array}{l}\text { nmedi- } \\
\text { water }\end{array}\right\}$ & 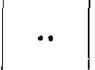 & “ & 47 & 85 \\
\hline " & $\left\{\begin{array}{c}\text { assed } \\
\text { tained on } 76\end{array}\right.$ & $"$ & " & *. & •• & 80 & 145 \\
\hline$"$ & $\left\{\begin{array}{c}\text { Passed } 76 \text { and re- } \\
\text { tained on } 120\end{array}\right\}$ & $"$ & $"$ & $\because$ & •• & 122 & 225 \\
\hline$"$ & $\left\{\begin{array}{r}\text { Passed } 120 \text { and } \\
\text { retained on } 180\end{array}\right\}$ & $"$ & $"$ & “ & $\ddot{*}$ & 280 & 430 \\
\hline$"$ & $\left\{\begin{array}{c}\text { Entire residue re- } \\
\text { tained on } 180\end{array}\right\}$ & $"$ & $"$ & 53 & 110 & 170 & 260 \\
\hline
\end{tabular}

the substitution of particles of sand for the coarse particles of cement does not seem to affect the result to the same extent, in every case the extreme fine grinding decreases its cohesive power, but immensely increases its adhesive power or cementitious value. These results demonstrate clearly that in testing cement, to determine its constructive value, the neat test alone may be altogether delusive. It will be seen that in each case the fine 
cement is far inferior to the coarse one when tested neat, yet its cementitious value, as indicated by its power of cementing together particles of sand, is immensely superior. Until recently the Author was strongly adverse to the adoption of the sand test, inasmuch as it first involved the testing of the sand, thus adding a further element of error; but when it is found that a very finely-ground cement, with more than 30 per cent. greater cementitious value, gives inferior results when tested neat, there is no doubt as to which is the truer test of the two. Moreover, in the course of recent researches as to the effect of admixtures of Kentish Ragstone, \&c., upon Portland cement, the Author found that it was possible, in some cases, to add as much as 20 per cent. to 30 per cent. of finelyground sand to a cement without materially affecting its strength when tested neat, although when tested as a mortar with 3 parts of standard sand the adulteration was immediately detected. ${ }^{1}$

The coarse residue separated from each of the foregoing samples was divided into different grades, and was washed and treated in an exactly similar manner to samples $\mathrm{A}, \mathrm{B}, \mathrm{C}, \mathrm{D}$ and $\mathrm{E}$, with the results given in Table III. Although the method adopted to avoid the possibility of fine dust adhering to the particles was severe, the results show that at all events in wet situations, where water is able to act upon them, the coarser particles of cement have a distinct value, and that this value is, roughly speaking, inversely proportional to the diameter of the particles. A microscopic examination of a section of a briquette composed wholly of such coarse particles shows that each particle is surrounded and cemented together by a white deposit of a crystalline nature; this deposit, in briquettes composed of residue on a 50-mesh sieve of cements $\mathrm{C}$ and $\mathrm{D}$, was separated mechanically as far as possible, and proved on analysis to consist as follows:-

\begin{tabular}{|c|c|c|c|c|c|c|c|c|c|c|c|}
\hline & & & & & & & & & & c. & n. \\
\hline \multirow[t]{2}{*}{$\begin{array}{l}\text { Carbonic acid } \\
\text { Water'. } \\
\text { Insoluble residue } \\
\text { Silica. } \\
\text { Alumina and oxide } \\
\text { Lime : } \cdot \text { : } \\
\text { Magnesia: : } \\
\text { Sulphuric acid : } \\
\text { Alkalies and loss }\end{array}$} & 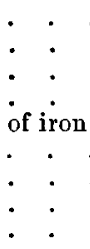 & 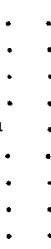 & $\dot{:} \cdot$ & $\dot{:} \cdot$ & 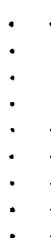 & $\begin{array}{l}\dot{:} \\
\dot{:} \\
\dot{:} \\
\dot{:} \\
\dot{.}\end{array}$ & 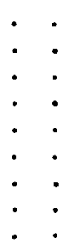 & 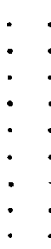 & 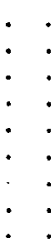 & $\begin{array}{r}11 \cdot 80 \\
24 \cdot 90 \\
\text { trace } \\
8 \cdot 12 \\
9 \cdot 22 \\
43 \cdot 47 \\
0 \cdot 99 \\
1 \cdot 35 \\
0 \cdot 15\end{array}$ & $\begin{array}{r}14 \cdot 00 \\
20 \cdot 60 \\
\text { trace } \\
6 \cdot 42 \\
8 \cdot 47 \\
48 \cdot 57 \\
0 \cdot 59 \\
1 \cdot 11 \\
0 \cdot 24\end{array}$ \\
\hline & & & & & & & & & & $100 \cdot 00$ & $100 \cdot 00$ \\
\hline
\end{tabular}

1 Transactions of the Society of Engineers, 1896, p. 179. 
A noteworthy feature of its composition is, that the percentage of alumina is considerably greater than that of the silica, thus reversing the composition of the cement proper, in which the amount of silica is generally about double that of the alumina, and indicating that the crystals consist largely of the more soluble aluminate of lime.

The foregoing results together suggest that the outer surface only of the coarser particle is acted upon or dissolved by the water, and as the finer the particle, the greater the area of such outer surface exposed to the action of the water within a given space, the greater is the cementitious value of that particle. At what fineness the particle becomes wholly active, and contains no internal inert matter, has yet to be determined; it seems, however, from these experiments, that those particles which pass through a 120 and are retained on a 180-mesh sieve, nearly approach that point, inasmuch as at 12 months they develop about four-sevenths of the strength of the original cement, notwithstanding the drastic treatment to which they were subjected in order to remove any trace of adhering dust.

It will be noticed in Table II that the finer grinding has a marked effect on the setting properties of the cement; sample I, for instance, commencing to set in 20 minutes in its original condition, while, when ground fine, its initial set is quickened to 2 minutes. This induced the Author to ascertain the effect of extreme fine grinding upon other samples, the results of which are given in Table IV. It will be seen in each instance that the finer grinding of the sample enormously quickens its setting properties. Although this fact is not generally recognised, its explanation is obvious, for it is evident that the finer the cement, the more readily the water can act upon it, and therefore the quicker the setting takes place. According to Le Chatelier the setting of cement is due to the formation of a supersaturated solution, which gradually deposits crystals until a solid mass is formed; if this theory is correct, it is clear that the finer the cement the more readily it dissolves, and therefore the sooner the supersaturated solution forms, and the quicker the crystals are deposited.

About 15 years ago it was the custom to determine the hea evolved by a cement during setting, as indicating its setting properties, and when the pat had returned to its original temperature, the sample was considered set. This test was shortly afterwards abandoned, and the present test of a weighted needle substituted, which is obviously the truer test for the purpose, for it is not easy to see the relation between the return to normal temperature and 
TABLE IV.

\begin{tabular}{|c|c|c|c|c|c|c|c|c|c|}
\hline \multirow{2}{*}{ 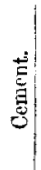 } & \multirow[t]{2}{*}{ How Treated. } & \multicolumn{3}{|c|}{$\begin{array}{l}\text { Fineness-residue } \\
\text { per cent, on Sieves } \\
\text { of Meshes per } \\
\text { Lineal Inch: }\end{array}$} & \multicolumn{2}{|c|}{ Setting Properties. } & \multirow{2}{*}{$\begin{array}{c}\text { Increase in } \\
\text { Tempera- } \\
\text { ture during } \\
\text { Setting. }\end{array}$} & \multirow{2}{*}{ 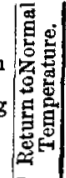 } & \multirow{2}{*}{$\begin{array}{l}\text { Pat treated in } \\
\text { Faija Apparatus } \\
\text { for Soundoess. }\end{array}$} \\
\hline & & 180 & 76 & 50 & Initial Set. & SetHard & & & \\
\hline$"$ & $\left\{\begin{array}{c}\text { As received } \\
\text { from manu- } \\
\text { facturer } \\
\text { Reground to } \\
\text { pass } 180 \\
\text { sieve }\end{array}\right\}$ & Trace & Nil & $\mathrm{Nil}$ & $\begin{array}{c}\text { Minutes. } \\
25\end{array}$ & Minntes & $\begin{array}{l}{ }^{\circ} \mathrm{F} . \text { Mins. } \\
22 \text { in } 40 \\
38 \text { in } 5\end{array}$ & Ms. & Sound. \\
\hline $\boldsymbol{K}$ & $\begin{array}{c}\text { As received } \\
\left\{\begin{array}{c}\text { Reground as } \\
\text { above }\end{array}\right\}\end{array}$ & $\left\{\begin{array}{l}26 \cdot 6 \\
\text { Trace }\end{array}\right.$ & $\begin{array}{c}10 \cdot 0 \\
\mathrm{Nil}\end{array}$ & $\begin{array}{c}2 \cdot 7 \\
\mathrm{NiI}\end{array}$ & $\begin{array}{r}30 \\
6\end{array}$ & $\begin{array}{l}90 \\
15\end{array}$ & $\begin{array}{l}17 \text { in } 100 \\
32 \text { in } 11\end{array}$ & $\left|\begin{array}{l}240 \\
150\end{array}\right|$ & $\begin{array}{c}\text { Sound. } \\
",\end{array}$ \\
\hline $\mathbf{L}$ & $\begin{array}{c}\text { As received } \\
\left\{\begin{array}{c}\text { Reground as } \\
\text { above }\end{array}\right\}\end{array}$ & $\begin{array}{l}24 \cdot 4 \\
\text { Trace }\end{array}$ & $\begin{array}{l}7 \cdot 6 \\
\text { Nil }\end{array}$ & $\begin{array}{c}1 \cdot 5 \\
\mathrm{Nil}\end{array}$ & $\begin{array}{r}30 \\
7\end{array}$ & $\begin{array}{r}120 \\
15\end{array}$ & $\begin{array}{r}9 \text { in } 60 \\
29 \text { in } 13\end{array}$ & $\begin{array}{l}180 \\
120\end{array}$ & $\begin{array}{l}\text { Blown. } \\
\text { Sound. }\end{array}$ \\
\hline M & $\begin{array}{c}\text { As received } \\
\left\{\begin{array}{c}\text { Reground as } \\
\text { above }\end{array}\right\}\end{array}$ & $\left\{\begin{array}{l}30 \cdot 0 \\
\text { Trace }\end{array}\right.$ & $\mid \begin{array}{c}6 \cdot 7 \\
\text { Nil }\end{array}$ & $\begin{array}{c}1 \cdot 2 \\
\mathrm{Nil}\end{array}$ & $\begin{array}{r}20 \\
2\end{array}$ & $\begin{array}{l}60 \\
10\end{array}$ & $\begin{array}{rr}21 \text { in } & 34 \\
26 \text { in } & 8\end{array}$ & $\begin{array}{r}150 \\
75\end{array}$ & $\begin{array}{c}\text { Sound. } \\
, "\end{array}$ \\
\hline $\mathbf{N}$ & $\begin{array}{c}\text { As received } \\
\left\{\begin{array}{c}\text { Reground as } \\
\text { above }\end{array}\right\}\end{array}$ & $\begin{array}{l}28 \cdot 4 \\
0 \cdot 6\end{array}$ & $\begin{array}{c}9 \cdot 3 \\
\mathrm{Nil}\end{array}$ & $\begin{array}{c}1 \cdot 0 \\
\mathrm{NiI}\end{array}$ & $\begin{array}{r}15 \\
1\end{array}$ & $\begin{array}{l}30 \\
10\end{array}$ & $\begin{array}{rr}25 \text { in } & 21 \\
32 \text { in } & 4\end{array}$ & $\begin{array}{l}120 \\
120\end{array}$ & $\begin{array}{c}\text { Sound. } \\
n\end{array}$ \\
\hline$"$ & $\begin{array}{c}\text { As received } \\
\left\{\begin{array}{c}\text { Reground as } \\
\text { above }\end{array}\right\}\end{array}$ & $\begin{array}{l}26 \cdot 4 \\
0 \cdot 4\end{array}$ & $\begin{array}{c}7 \cdot 7 \\
N \text { NiI }\end{array}$ & $\begin{array}{c}0.5 \\
\text { Nil }\end{array}$ & $\left\{\begin{array}{c}\text { Unde- } \\
\text { finable }\end{array}\right\}$ & $\begin{array}{r}360 \\
25\end{array}$ & $\left|\begin{array}{rr}2 \text { in } & 39 \\
27 \text { in } & 12\end{array}\right|$ & 95 & Sound. \\
\hline $\mathbf{P}$ & 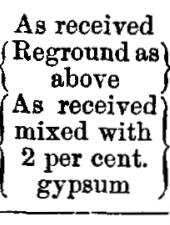 & $\begin{array}{l}18 \cdot 0 \\
0.4\end{array}$ & $\begin{array}{c}3 \cdot 0 \\
\mathrm{Nil} \\
3 \cdot 0\end{array}$ & $\begin{array}{c}0.8 \\
\mathrm{Nil} \\
0.8\end{array}$ & $\left\{\begin{array}{c}15 \\
2 \\
\text { Unde- } \\
\text { finable }\end{array}\right\}$ & $\begin{array}{r}240 \\
240 \\
1,440\end{array}$ & $\left|\begin{array}{rr}15 \text { in } & 23 \\
23 \text { in } & 5 \\
1 \text { in } & 15\end{array}\right|$ & $\begin{array}{l}120 \\
100 \\
35\end{array}$ & 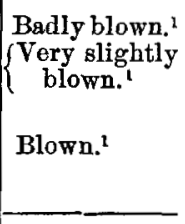 \\
\hline$Q$ & $\left.\begin{array}{c}\text { As received } \\
\text { Reground as } \\
\text { above } \\
\text { As received } \\
\text { mixed with } \\
2 \text { per cent. } \\
\text { gypsum }\end{array}\right\}$ & $\begin{array}{r}34 \cdot 8 \\
1 \cdot 6\end{array}$ & $\left|\begin{array}{c}16 \cdot 0 \\
\mathrm{Nil} \\
16 \cdot 0\end{array}\right|$ & $\begin{array}{c}3 \cdot 6 \\
\text { Nil } \\
3 \cdot 6\end{array}$ & $\begin{array}{c}20 \\
2 \\
\left\{\begin{array}{c}\text { Unde- } \\
\text { finable }\end{array}\right.\end{array}$ & $\begin{array}{r}30 \\
5 \\
1,440\end{array}$ & $\left|\begin{array}{rr}17 \text { in } & 35 \\
26 \text { in } & 5 \\
1 \text { in } & 15\end{array}\right|$ & $\begin{array}{l}180 \\
180\end{array}$ & $\begin{array}{l}\text { Badly blown. } \\
\text { Sound. } \\
\text { Blown. }\end{array}$ \\
\hline
\end{tabular}

'A specially-preparedj" over-limed" cement; see analysis, Table V. 
the setting of the sample. Mr. G. F. Deacon has advocated ${ }^{1}$ the determination of the rise of temperature during setting as a test for "free lime." The Author, however, doubts the utility of this test, and has expressed ${ }^{2}$ the opinion that the rise of temperature during setting of a cement is due rather to the heat evolved by crystallization or setting than to the presence of "free lime," and that such a test therefore only ensures an extremely slow-setting cement, and in no way ensures a sound one. To ascertain the relation between the setting properties of cement and the heat evolved during setting, and also how far the theory was correct, that little or no increase in temperature pointed to the absence of "free lime," that is, a sound cement, the rise of temperature during setting of each sample in Table IV was also noted, and in each case it was found to bear a distinct relation to the time oceupied in setting.

Table V.-Analyses of the Principal Cements used in the Fonegolng Experiments.

\begin{tabular}{|c|c|c|c|c|c|c|c|}
\hline- & & F. & G. & H. & I. & P. & Q. \\
\hline $\begin{array}{l}\text { Water and carbon } \\
\text { Insoluble residue } \\
\text { Soluble silica. } \\
\text { Alumina : } \\
\text { Oxide of iron : } \\
\text { Lime : } \\
\text { Magnesia : } \\
\text { Sulphuric acid } \\
\text { Alkalies and loss }\end{array}$ & 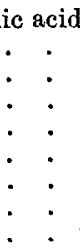 & $\begin{array}{r}1 \cdot 70 \\
0 \cdot 98 \\
20 \cdot 98 \\
8 \cdot 41 \\
4 \cdot 02 \\
60 \cdot 55 \\
1 \cdot 29 \\
1.67 \\
0 \cdot 40\end{array}$ & $\begin{array}{r}1 \cdot 55 \\
1 \cdot 08 \\
20 \cdot 75 \\
7 \cdot 48 \\
3 \cdot 81 \\
62 \cdot 01 \\
1 \cdot 14 \\
1 \cdot 83 \\
0 \cdot 35\end{array}$ & $\begin{array}{r}1 \cdot 40 \\
0 \cdot 77 \\
21 \cdot 04 \\
8 \cdot 17 \\
4 \cdot 21 \\
61 \cdot 23 \\
1 \cdot 27 \\
1 \cdot 39 \\
0 \cdot 52\end{array}$ & $\begin{array}{r}1 \cdot 55 \\
0 \cdot 68 \\
20 \cdot 05 \\
8 \cdot 55 \\
3 \cdot 94 \\
62 \cdot 19 \\
1 \cdot 23 \\
1 \cdot 49 \\
0 \cdot 32\end{array}$ & $\begin{array}{r}1 \cdot 25 \\
1 \cdot 49 \\
21 \cdot 43 \\
5 \cdot 77 \\
3 \cdot 51 \\
64 \cdot 20 \\
1 \cdot 08 \\
0 \cdot 68 \\
0 \cdot 59\end{array}$ & $\begin{array}{r}1 \cdot 45 \\
1 \cdot 17 \\
20 \cdot 57 \\
6 \cdot 46 \\
5 \cdot 38 \\
62 \cdot 09 \\
1 \cdot 34 \\
1 \cdot 12 \\
0 \cdot 47\end{array}$ \\
\hline & & $100 \cdot 00$ & $100 \cdot 00$ & $100 \cdot 00$ & $100 \cdot 00$ & $100 \cdot 00$ & $100 \cdot 00$ \\
\hline
\end{tabular}

Each sample was also tested for soundness in the Faija apparatus $^{3}$ and the results recorded; it will be seen that cement $L$, in its original condition, was unsound, although it only showed an increase of $9^{\circ}$ in 60 minutes; when extremely finely ground the heat evolved during setting was $29^{\circ}$ in 13 minutes, and the fine grinding had rendered it perfectly sound. The latter result was surprising, and efforts were thereupon made to procure one or two unsound cements, and ascertain the effect of grinding them extremely fine. Cement $P$ was specially prepared for the Author as an over-limed, unsound cement; when treated in the Faija apparatus it "blew" badly, and disintegrated almost entirely, but after being ground extremely fine, this "blowing" characteristic had

1 Minutes of Proceedings Inst. C.E., vol. cxxvi. p. 46.

2 Ibid, vol. exxvi. p. 103 . J Ibid, vol. Ixxv. p. 213-30. 
practically disappeared. Cement $Q$, on the other hand, was a badly manufactured cement, being made from a very hard chalk, insufficiently reduced during the amalgamation of the raw materials. This sample also "blew" very badly when treated in the Faija apparatus, but after being ground extremely fine, these indications disappeared entirely.

To ascertain more conclusively whether the action of setting or the presence of "free lime" was responsible for the rise in temperature noted, cements $\mathrm{P}$ and $\mathrm{Q}$ in their coarse condition were mixed with 2 per cent. of gypsum, which, as is well known, retards the setting of cement; the result was that they were thus rendered extremely slow setting, and while still unsound, and giving decided indications of "blowing" in the Faija apparatus, they showed an increase during setting of only $1^{\circ}$. As, therefore, the rise of temperature during setting depends upon the setting properties of the cement, and in no way determines the presence of "free lime" or other disruptive agencies, the Author is strongly of opinion that to enforce such a test, while it certainly ensures the delivery of a very slow-setting cement, which in view of the method of working adopted by Mr. Deacon was absolutely imperative, in no way guards against an unsound cement, and imposes needless restrictions upon the manufacturer. Unsound over-limed cements are generally slow setting, and therefore evolve little or no heat during setting, while, on the other hand, a case lately came under the Author's notice of a cement which withstood the severe hotwater test of Deval, and yet showed an increase of as much as $25^{\circ}$.

That the finer grinding of cement should, to a considerable extent, correct a tendency to "blow," is a most important feature, the reason of which may be readily explained. "Blowing" or unsoundness may generally be traced to one of two distinct faults in manufacture, viz., over-liming or excess of lime, under-burning or insufficient calcination, both giving rise to the presence of free or loosely combined lime. In the first case the cement contains more lime than the silica and alumina can properly combine with, and in the second, insufficient heat has been applied to enable the lime to chemically combine with the other constituents. Of these two forms of unsoundness, by far the most insidious and dangerous is that due to over-liming, as the uncombined lime is confined within the hard-burned coarser particles, and it may be weeks or even months before the water can penetrate sufficiently to cause it to expand and betray its presence. The unsoundness due to underburning, on the other hand, is comparatively harmless, and is gener- 
ally detected within a day or two; in contradistinction to the unsoundness dne to over-liming, which often causes the cement to crumble and disintegrate entirely, the under-burnt material behaves in much the same way as a fresh hydraulic lime, i.e., a few slight cracks, and nothing further ensues. The beneficial effect of fine grinding, therefore, is that the uncombined lime, which would otherwise be confined within the coarser particles and subsequently cause mischief, is hydrated by the water during: the operation of gauging, and thus rendered innocuous, or, if the cement has been previously spread out to mature, the moisture in the atmosphere acts upon it in a similar manner.

The effect of fine grinding on the setting properties of cement is a more serious matter, as in some instances it may render it too quick-setting for proper use. The tendency during the past few years has been to demand a finer cement, and at the same time a slow-setting one. The experiments in Tables II and IV show these two characteristics to be absolutely antagonistic, and unless it is rendered slow-setting artificially, a finely-ground cement means a quick-setting one, according to the degree of fineness attained. There are two methods of rendering a cement slow-setting: first, by thorough aeration, by which means the aluminate of lime becomes partially hydrated and its activity modified; secondly, by the addition of small percentages of gypsum ground up with the clinker in the course of manufacture. The latter method is largely practised in Germany, and within 2 per cent. the addition of that material is sanctioned by the German Cement Manufacturers Association. The ultimate effect of an addition of gypsum has not, in the Author's opinion, been sufficiently investigated to authorize its being accepted without reserve; his experience is that the addition of very small quantities, even as little as $\frac{1}{2}$ per cent., will materially modify the quick-setting properties of a cement, but it seems somewhat easy to overstep the mark, inasmuch as 5 per cent. causes decided disintegration. According to certain continental authorities, the addition of gypsum should not be sanctioned where the cement is to be used in sea-water, as the salts contained therein have a very prejudicial effect upon cements containing such admixtures.

The Author therefore concludes:-

(1) The coarser particles of cement are not inert, but have a certain value, approximately in inverse ratio to their diameter.

(2) The extreme fine grinding of cement decreases its cohesive power, but immensely increases its adhesive power, and consequently its value quâ cement. Therefore to ascertain the true

[THE INST. C.E. VOL. CXXXII.] 
$35 \pm$ BUTLER ON FINER GRINDING OF PORTLAND CEMENT. [Selected

constructive value of a sample, it should always be tested with a certain proportion of sand in addition to being tested neat.

(3) The finer grinding of cement immensely quickens its setting properties, and therefore allowance should be made in this respect, unless admixtures of gypsum or other artificial means of rendering it slow-setting are to be permitted.

(4) The finer grinding of cement largely corrects a tendency to unsoundness. A cement that would be totally unfit for use on this account when coarsely ground, would be perfectly reliable when extremely fine, owing to the water being able to attack the uncombined lime during the operation of gauging, instead of weeks or, maybe, months afterwards, when confined within the coarse particles.

(5) Increase in temperature during setting is governed by the setting properties of the sample. The setting of cement, being a process of crystallization, evolves heat; and the quicker the setting, the more intense the action, and therefore the greater the rise of temperature. That the cement shall show little or no rise of temperature during setting, ensures an extremely slow-setting cement, but does not guard against an unsound one.

With the exception of cements F, G, H, I, and P, which were chosen for the special reasons stated, the samples used in the experiments were not selected for that purpose, but were ordinary English cements passing through the Author's hands for testing in the usual course. Cements $B$ and $G$ were made by the same manufacturers, also samples $H$ and $L$; but the remainder emanated from different factories.

The Paper is accompanied by six micro-sections of briquettes, and by photographs of pats treated in the Faija apparatus, which may be consulted at the Institution. 